\title{
Tournaisian miospore assemblages from Maesbury in the eastern Mendips, England
}

\author{
K. HIGGS \& G. CLAYTON \\ Geological Survey of Ireland, 14 Hume Street, Dublin 2, Ireland \& \\ Department of Geology, Trinity College, Dublin 2, Ireland
}

\begin{abstract}
Miospore assemblages are described from a section of the Lower Limestone Shale and the lower part of the Black Rock Limestone at Maesbury in the eastern Mendips. Conodont evidence indicates the miospore assemblages are Middle to Upper Tournaisian $(\operatorname{Tn} 2-\operatorname{Tn} 3)$ in age. The assemblages are compared to those obtained from other areas, particularly southern Ireland. One new species Discernisporites sullivanii is erected and one new spore type is described.
\end{abstract}

\section{INTRODUCTION}

In the Mendip Hills of southwest England sediments of the 'Old Red Sandstone' magna-facies pass conformably up into the marine Lower Limestone Shale. This is succeeded by a thick carbonate succession of which the Black Rock Limestone is the lowest division. The uppermost 'Old Red Sandstone' is considered, from miospore evidence, to be Lower Tournaisian (Tn1) in age (Dolby \& Neves, 1970; Dolby, 1970). Studies of macro and microfaunas have shown the Lower Limestone Shale and the Black Rock Limestone to be Middle to Upper Tournaisian (Tn2-Tn3) in age (George et al., 1976; Butler, 1973).

Previous palynological work at this stratigraphical level in southwest Britain has been concentrated at the 'Old Red Sandstone' - Lower Limestone Shale boundary (Dolby \& Neves, 1970; Dolby, 1970; Utting \& Neves, 1970; Gayer et al., 1973 and Bassett \& Jenkins, 1977). The present study was undertaken to investigate the miospore assemblages occurring in the upper part of the Lower Limestone Shale and the lower part of the Black Rock Limestone, and to compare the assemblages with those obtained from successions of similar age in other areas, particularly southern Ireland. In this latter area the miospore succession has been described in detail in recent years (see Clayton \& Higgs, 1979), and much of this work has been allied with conodont studies (Clayton et al., 1977, 1980; Johnston \& Higgins, 1981). The conodont biostratigraphy established at Maesbury by Butler (1973) provides independent support for the proposed palynological correlations between Maesbury and southeast Ireland.

\section{LOCATION AND STRATIGRAPHY}

At Maesbury (Nat. Grid Ref.: ST606475) in the eastern Mendips a disused railway cutting on the south side of the B3135 road exposes the upper two thirds of the Lower Limestone Shale and the lowermost part of the Black Rock Limestone. The stratigraphy of this section has been described by Green \& Welch (1965) and by Butler (1973). The latter author also made a detailed study of the conodont faunas occurring in the rocks and divided the section into five lithostratigraphical units which are used in the present study (see Fig. 2).

The location of the section and stratigraphical positions of the samples described in the present study are shown in Figs. 1-2 respectively. All the samples were collected at or just above the track level at distances from Maesbury Halt Bridge shown below (the stratigraphic positions of these samples are shown in Fig. 2):

$\begin{array}{llll}\text { Sample Ma } & 1 & \ldots & 221.65 \mathrm{~m} \\ \text { Sample Ma } & 4 & \ldots & 270.12 \mathrm{~m} \\ \text { Sample Ma } & 5 & \ldots & 287.19 \mathrm{~m} \\ \text { Sample Ma } & 6 & \ldots & 335.36 \mathrm{~m} \\ \text { Sample Ma } & 9 & \ldots & 396.34 \mathrm{~m} \\ \text { Sample Ma } 12 & \ldots & 527.43 \mathrm{~m} \\ \text { Sample Ma } & 18 & \ldots & 567.68 \mathrm{~m} \\ \text { Sample Ma } 21 & \ldots & 593.29 \mathrm{~m} \\ \text { Sample Ma } 23 & \ldots & 602.13 \mathrm{~m}\end{array}$

\section{SAMPLE PREPARATION}

All the productive samples are dark grey calcareous mudrocks and were prepared using standard laboratory techniques. The organic residues were weakly carbonised and required only a few minutes oxidation in Schultze Solution. Permanent scatter mounts were made using 'Clearcol' dispersal agent and 'Elvacite' cold mounting medium. All figured specimens are housed in the Geological Survey of Ireland micropalaeontological collection in Dublin.

The miospores obtained are abundant and in the majority of cases well preserved, though a few samples contained pyritised spores. Fifty three miospores taxa were recorded. The majority of these are well described 


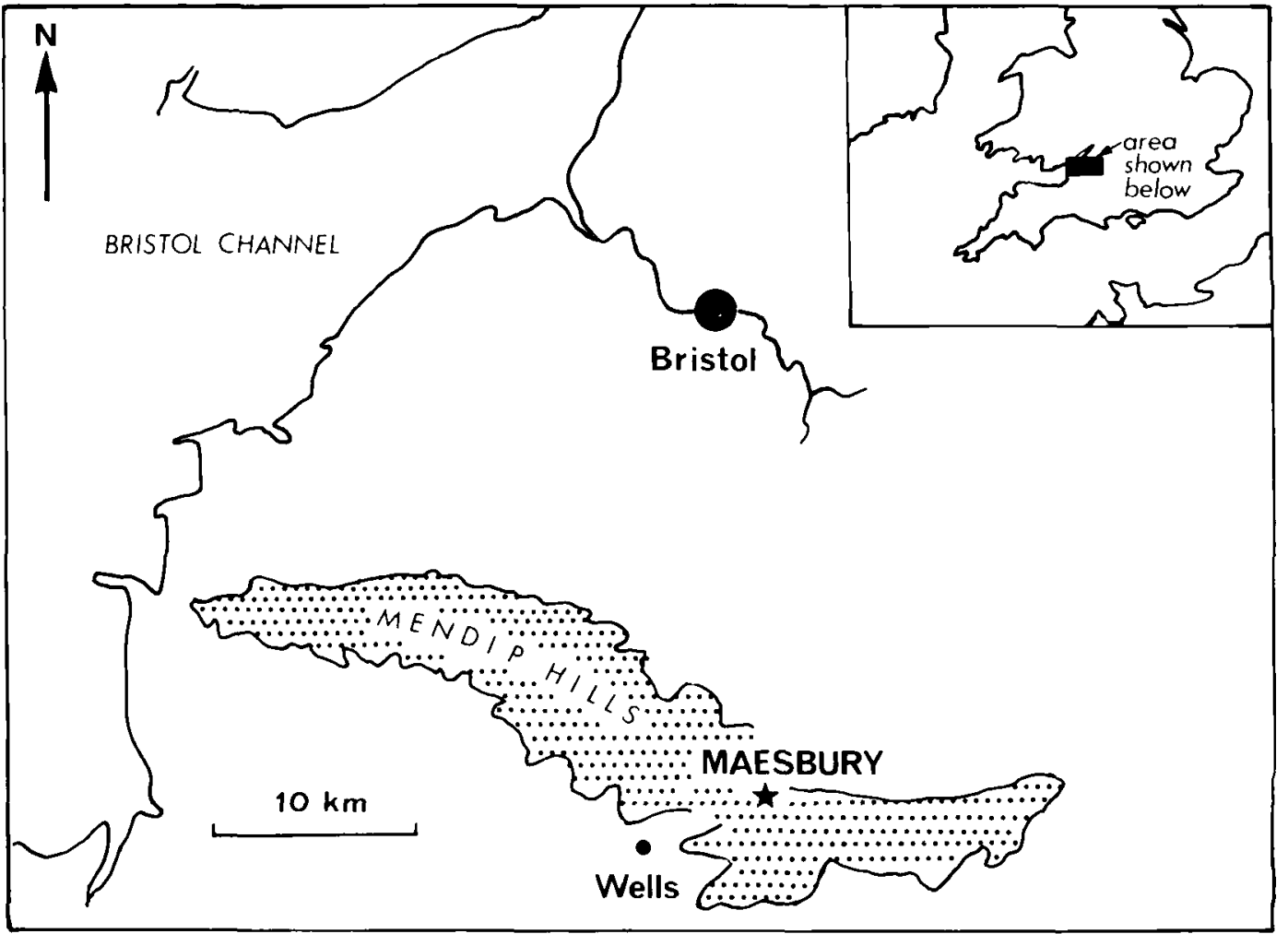

Fig. 1. Location of the section studied.

in the literature, so no formal systematic descriptions are given with the exception of one new species and one new type. The stratigraphical occurrence of all the taxa recorded is shown in Fig. 3. A selection of the stratigraphically more useful taxa is illustrated in Plates 1 and 2.

\section{SYSTEMATIC DESCRIPTIONS}

Anteturma Sporites H. Potonié, 1893

Turma Triletes (Reinsch) Dettman, 1963

Suprasubturma Acameratitriletes Owens \& Neves, 1966

Subturma Azonotriletes (Luber) Dettman, 1963

Infraturma Apiculati (Bennie \& Kidston)

$$
\text { R. Potonié, } 1956
$$

Genus Raistrickia Schopf Wilson \& Bentall emend.

Potonié \& Kremp, 1954

\section{Raistrickia sp. A}

(Pl. 1, figs. 22, 23)

Description. Acamerate miospores, amb subcircular to oval. Suturae usually obscured by ornament, simple, straight and extending almost to the equator. Exine $2 \mu \mathrm{m}$ in thickness, and densely ornamented with baculate and clavate processes $2.5-6 \mu \mathrm{m}$ in height, $1.5-3.5 \mu \mathrm{m}$ in width. Processes possess parallel, upwardly convergent or divergent sides, and terminate in flat, rounded, or slightly expanded tops. Bases of ornament discrete or sometimes fused. Ornament slightly reduced on proximal surface.

Dimensions. $42-47 \mu \mathrm{m}$, based on 4 specimens.

Remarks. The specimens recorded are very close to Raistrickia pinguis Playford, 1971 from the Lower Carboniferous of Western Australia, however they differ in possessing more slender elongated bacula and clava.

Suprasubturma Cameratitriletes Neves \& Owens, 1966 Subturma Continuati Neves \& Owens, 1966

Genus Discernisporites Neves, 1958 emend. Neves \& Owens, 1966

Discernisporites sullivanii sp. nov.

(Pl. 2, figs. 14, 15)

1964 Discernisporites sp. Sullivan: p. 1255, figs. 5, 9.

1970 Discernisporites sp. Utting \& Neves: pl. 27, fig. 3.

1978 Discernisporites sp. Keegan \& Penney: pl. 1, fig. 6.

1978 Discernisporites micromanifestus (Hacquebard)

Sabry \& Neves in Turnau: pl. 5, figs. 1-2, non fig. 4 .

1980 Discernisporites sp. A. Clayton, Johnston, Sevastopulo \& Smith: pl. 3, fig. M.

Derivation of name. After Dr. H. J. Sullivan, who made the first palynological study of the Lower Limestone Shale.

Diagnosis. Trilete camerate miospores. Amb convexly 
triangular. Suturae accompanied by sinuous and flexuous ray folds, $3-7 \mu \mathrm{m}$ in height, which extend to the spore margin. Intexine distinct to barely perceptible, with outline conformable with amb. Intexine laevigate, diameter $1 / 2$ to $4 / 5$ of the total diameter. Exoexine ornamented distally with grana and coni. Elements $0.5-2.5 \mu \mathrm{m}$ in height, $1-1.5 \mu \mathrm{m}$ in diameter, discrete or fused to form short rugulae up to $5 \mu \mathrm{m}$ in length. Ornament is densely to evenly distributed over the distal surface or occasionally concentrated at the distal pole. Exine often bears large taper point compression folds and three variably defined apical papillae.

Holotype. Pl. 2, fig. 14.

Locality and horizon. Sample Ma6, Lower Limestone Shale, Maesbury, eastern Mendips, England.
Dimensions. 60-(74)- 1. . . (based on 18 specimens). Remarks. Discernisporites micromanifestus (Hacquebard) Sabry \& Neves, 1970 is similar in structure but differs in possessing an unornamented or finely infragranulate exine. The specimen figured as $D$. micromanifestus by Sabry \& Neves (1970, pl. 3 fig. 11) appears to be ornamented and is probably assignable to $D$. sullivanii. Discernisporites irregularis Neves, 1958 differs from D. sullivanii in possessing irregular plications concentrated at the distal polar region.

\section{COMPOSITION OF MIOSPORE ASSEMBLAGES}

Miospores have been obtained from nine samples. The composition of each assemblage is shown in Fig. 3.

Two distinct miospore assemblage types can be

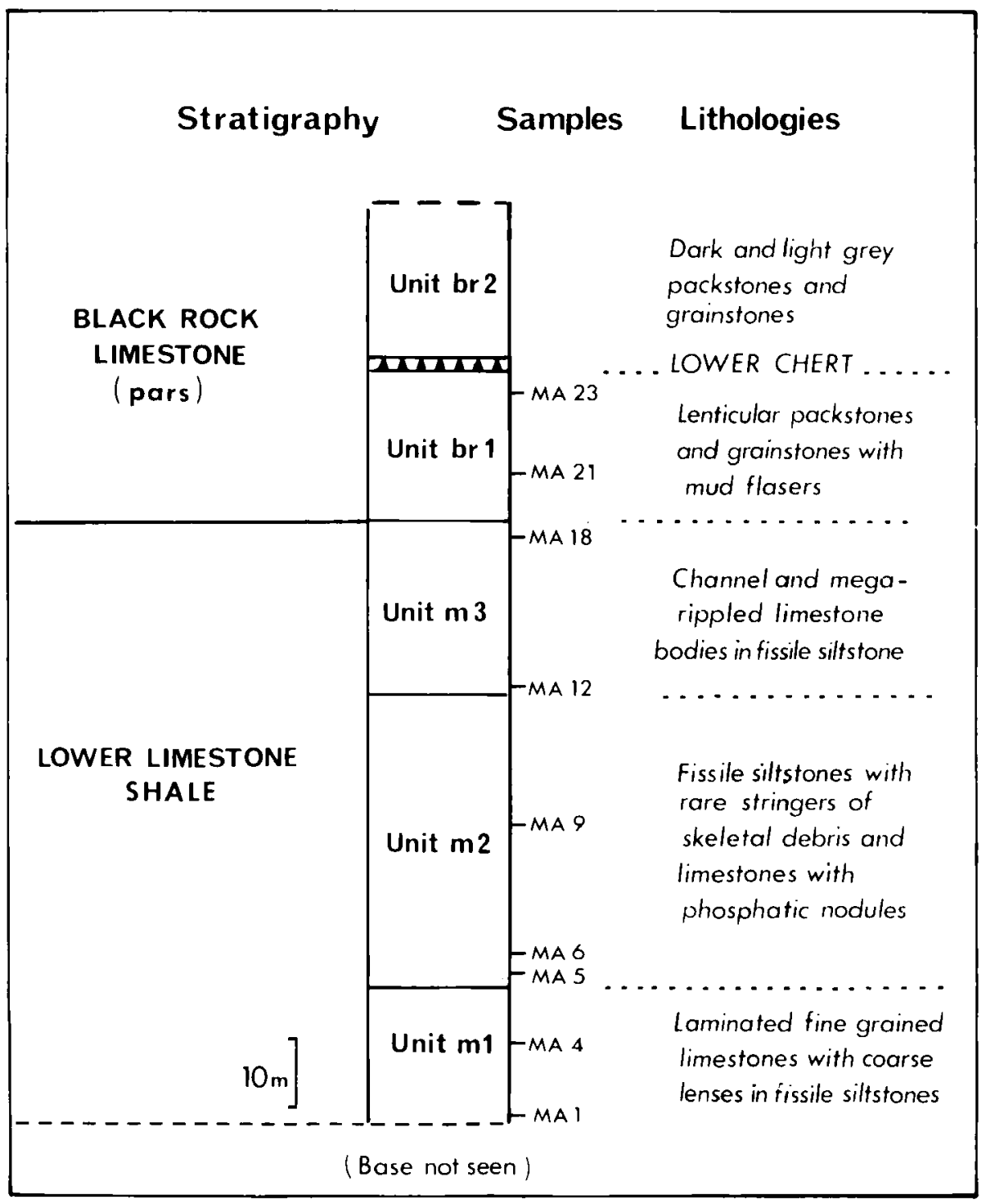

Fig. 2. Lithostratigraphy of the section (after Butler, 1973) showing the stratigraphic position of the productive samples. 
recognised. The lower assemblage type is characterised by the following association of species: Verrucosisporites nitidus (Naumova) Playford, Kraeuselisporites hibernicus Higgs, Spelaeotriletes balteatus (Playford) Higgs,
S. obtusus Higgs, Hymenozonotriletes explanatus (Luber) Kedo, Umbonatisporites distinctus Clayton, Rugospora polyptycha Neves \& Ioannides and Vallatisporites vallatus Hacquebard. This assemblage occurs in samples

\begin{tabular}{|c|c|}
\hline 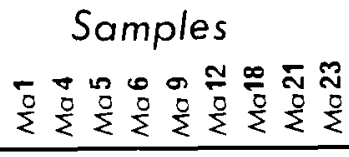 & MIOSPORE TAXA \\
\hline 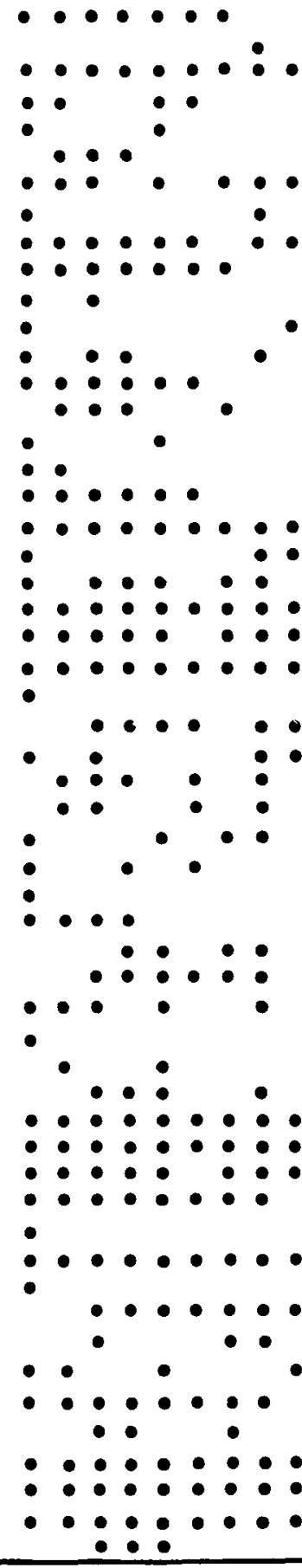 & $\begin{array}{l}\text { Acanthotriletes persibus } \\
\text { Apiculatasporites cf. compactus } \\
\text { Auroraspora macra } \\
\text { A. solisorta } \\
\text { A. cf. panda } \\
\text { Asperispora acuta } \\
\text { Baculatisporites fusticulus } \\
\text { Camptotriletes prionotus } \\
\text { Convolutispora oppressa } \\
\text { C. vermiformis } \\
\text { C. cf. finis } \\
\text { Corbulispora cancellata } \\
\text { Cristatisporites colliculus } \\
\text { Cymbosporites magnificus } \\
\text { Densosporites spitsbergensis } \\
\text { Dictyotriletes subalveolaris } \\
\text { D. submarginatus } \\
\text { D. trivialis } \\
\text { Discernisporites sullivanii } \\
\text { Endoculeospora gradzinskii } \\
\text { Grandispora echinata } \\
\text { Hymenozonotriletes explanatus } \\
\text { Knoxisporites literatus } \\
\text { Kraeuselisporites hibernicus } \\
\text { K. fasciatus } \\
\text { K. mitratus } \\
\text { Lophozonotriletes triangulatus } \\
\text { L. tuberosus } \\
\text { Murospora dubitata } \\
\text { Pulvinispora scolecophora } \\
\text { Punctatisporites planus } \\
\text { Pustulatisporites gibberosus } \\
\text { P. sp. A } \\
\text { Raistrickia clavata } \\
\text { R. condylosa } \\
\text { R.corynoges } \\
\text { R.variabilis } \\
\text { R. sp. A } \\
\text { Retusotriletes communis } \\
\text { R. crassus } \\
\text { R.incohatus } \\
\text { Rugospora polyptycha } \\
\text { Schopfites delicatus } \\
\text { S. sp. A } \\
\text { Spelaeotriletes balteatus } \\
\text { S. obtusus } \\
\text { S. pretiosus } \\
\text { Spinozonotriletes uncatus } \\
\text { Umbonatisporites distinctus } \\
\text { Vallatisporites vallatus } \\
\text { V. verrucosus } \\
\text { Velamisporites mognus } \\
\text { SColrucosisporites nitidus } \\
\text { ACRITARCHS } \\
\end{array}$ \\
\hline
\end{tabular}

Fig. 3. Occurrence of all the miospore taxa recorded in the Maesbury samples. 
MA1 and MA4, from lithostratigraphic Unit M1 of the Lower Limestone Shale.

The upper assemblage type contains most of the taxa listed above together with the following group of species: Spelaeotriletes pretiosus (Playford) Neves \& Belt, Kraeuselisporites mitratus Higgs, Raistrickia condylosa Higgs and Raistrickia clavata Hacquebard emend. Playford. The last named species first appears at a slightly higher level than the others (Ma6). The upper assemblage is first recognised in sample Ma5, immediately above the base of lithostratigraphical unit $\mathrm{M} 2$, and occurs in the succeeding samples of the Lower Limestone Shale and basal part of the Black Rock Limestone. The qualitative composition of these assemblages is generally constant. The stratigraphically significant species Spelaeotriletes pretiosus is notably rare in sample Ma5 (only 2 specimens recorded) but becomes more abundant $(\geqslant 5 \%)$ in succeeding samples.

All the samples studied contain scolecodonts and a few contain rare acritarchs.

\section{BIOSTRATIGRAPHY}

Both the assemblage types described can be related to the miospore zonal scheme for the British and Irish Dinantian. This scheme was originally described by Neves et al. (1972, 1973), but has since been modified (particularly the Tournaisian part) by Clayton et al. (1978).

The lower assemblage type is assigned to the Vallatisporites verrucosus - Retusotriletes incohatus (VI) SubBiozone of the Verrucosisporites nitidus - Vallatisporites verrucosus (NV) Biozone. The presence of the species Spelaeotriletes balteatus, Rugospora polyptycha, Kraeuselisporites hibernicus and Vallatisporites vallatus indicates a position in the upper part of the VI SubBiozone. According to Clayton et al. (1978, text fig. 1), this would be indicative of a $\operatorname{Tn} 2$ age.

The upper assemblage type is assigned to the Spelaeotriletes pretiosus - Raistrickia clavata (PC) Biozone. The base of this biozone correlates with a level within Tn2b or Tn2c (see Clayton et al., 1978, p. 142). The age of the upper limit of the PC Biozone is not precisely known, though conodont faunas associated with PC Biozone assemblages indicate the biozone ranges well up into Tn3, (see Clayton et al., 1978, p. 142).

The conodont faunas obtained by Butler (1973) from the Lower Limestone Shale and Black Rock Limestone support the ages quoted above. His conodont biostratigraphy is closely comparable with that described by Johnston \& Higgins (1981) from the Porters Gate and Hook Head Limestone Formations at Hook Head in County Wexford, Ireland. These latter authors erected a local conodont zonation and were able to correlate their zones with the Maesbury succession. Correlation of their lower zones is shown in Fig. 4; it can be seem that both at Hook Head and Maesbury the Polygnathus spicatus Zone is associated with upper VI and lowermost PC Zone miospore assemblages and the Polygnathus inornatus Zone is associated entirely with PC Zone miospore assemblages.

\section{CHRONOSTRATIGRAPHY}

In terms of chronostratigraphy, the sequence studied is included in the Courceyan Stage of George et al. (1976). Ramsbottom \& Mitchell (1980) have proposed the use of the Belgian Tournaisian stages 'Hastarian' and 'Ivorian' to replace the Courceyan in the British Isles, but their use in this region has not been generally accepted because of considerable uncertainties concerning the correlation of their boundaries (see Clayton \& Sevastopulo, 1980 and Johnston \& Higgins, 1981 for detailed discussion).

\section{COMPARATIVE STRATIGRAPHIC PALYNOLOGY Burrington Combe}

Miospore assemblages from the upper part of the Old Red Sandstone and the Lower Limestone Shale at Burrington Combe in the western Mendips, have been described by Dolby \& Neves (1970) and Dolby (1970).

Miospore assemblages recorded by Dolby from $52 \mathrm{~m}$ and $9 \mathrm{~m}$ below the base of the Lower Limestone Shale in Burrington Combe can be assigned to the PL Biozone (Clayton et al., 1978). The lower of these samples is assigned to the LL Sub-Biozone, whereas the upper sample contains Hymenozonotriletes explanatus (Luber) Kedo, and is therefore assigned to the LE Sub-Biozone. A single assemblage recorded by Dolby (1970) from $8 \mathrm{~m}$ below the base of the Lower Limestone Shale includes the association of Retispora lepidophyta (Kedo) Playford and Verrucosisporites nitidus (Naumova) Playford, and is assigned to the LN Sub-Biozone of the NV Biozone.

Several samples ranging from $5 \mathrm{~m}$ to $82 \mathrm{~m}$ above the base of the Lower Limestone Shale are assigned to the VI Sub-Biozone of the NV Biozone. In a sample from $82 \mathrm{~m}$ above the base of the Lower Limestone Shale $S$. pretiosus appeared for the first time, marking the base of the PC Biozone.

\section{Avon Gorge}

Utting \& Neves (1970) described miospore assemblages from the Old Red Sandstone - Lower Limestone Shale transition measures in the classic section of the Avon Gorge, near Bristol. Samples were investigated from the Portishead Beds, the Shirehampton Beds and the lower part of the Lower Limestone Shale. They were able to recognise three succeeding types of assemblage. Their lowermost assemblage occurred approximately $37 \mathrm{~m}$ below the Rhacophyton Bed and is assigned to the LL Sub-Biozone of the PL Biozone. Their middle 


\section{Explanation of Plate 1}

All figures are $\times 500$.

Fig. 1. Punctatisporites planus Hacquebard, Ma6A 4541130.

Fig. 2. Retusotriletes incohatus Sullivan, Ma1B 528968.

Fig. 3. Pulvinispora scolecophora Neves \& Ioannides, Ma9A 314982.

Fig. 4. Acanthotriletes persibus Higgs, Ma1A 4521126.

Fig. 5. Apiculatasporites cf. compactus Playford, Ma21D 463980.

Fig. 6. Pustulatisporites sp. A sensu Higgs, Ma1B 2011040.

Fig. 7. Umbonatisporites distinctus Clayton, Ma4B 2481092.

Fig. 8. Schopfites delicatus Higgs, Ma6A 3501125.

Fig. 9. Schopfites sp. A sensu Higgs, Ma1B 2321126.

Fig. 10. Lophozonotriletes triangulatus Playford, Ma21A, 3201060.

Fig. 11. Dictyotriletes trivialis Naumova in litt Kedo, Ma1B 2711080.

Fig. 12. Cymbosporites magnificus (McGregor) McGregor \& Camfield, Ma9B 3391130.

Fig. 13. Corbulispora cancellata (Waltz) Bharadwaj \& Ventakachala, Ma1A 3641048.

Fig. 14. Lophozonotriletes tuberosus Sullivan, Ma21C 465982.

Fig. 15. Verrucosisporites nitidus (Naumova) Playford, Ma21C 5571137.

Fig. 16. Verrucosisporites nitidus (Naumova) Playford, Ma210 4771100.

Fig. 17. Raistrickia condylosa Higgs, Ma6A 3401125.

Fig. 18. Murospora dubitata Higgs, Ma5A 2371078.

Fig. 19. Raistrickia clavata Hacquebard emend. Playford, Ma6A 222111.

Fig. 20. Raistrickia corynoges Sullivan, Ma1B 340977.

Fig. 21. Raistrickia corynoges Sullivan, Ma1C 3421030.

Fig. 22. Raistrickia sp. A. Ma4B 3451025.

Fig. 23. Raistrickia sp. A, Ma4B 2651005. 




\section{Explanation of Plate 2}

All figures are $\times 500$.

Fig. 1. Spelaeotriletes balteatus (Playford) Higgs, Ma6B 5971038.

Fig. 2. Spelaeotriletes pretiosus (Playford) Neves \& Belt, Ma9B 382963.

Fig. 3. Kraeuselisporites mitratus Higgs, Ma6D 304975.

Fig. 4. Grandispora echinata Hacquebard, Ma1B 4871064.

Fig. 5. Hymenozonotriletes explanatus (Luber) Kedo, Ma1B 238958.

Fig. 6. Rugospora polyptycha Neves \& Ioannides, Ma6A 2671110.

Fig. 7. Kraeuselisporites hibernicus Higgs, Ma6B 6071132.

Fig. 8. Kraeuselisporites hibernicus Higgs, Ma21E 5371137.

Fig. 9. Vallatisporites verrucosus Hacquebard, Ma6A 4781138.

Fig. 10. Vallatisporites vallatus Hacquebard, Ma9C 230930.

Fig. 11. Hymenozonotriletes explanatus (Luber) Kedo, Ma1A 468946.

Fig. 12. Velamisporites magnus (Hughes \& Playford) Playford, Ma1A 3981013.

Fig. 13. Endoculeospora gradzinskii Turnau, Ma1A 5331076.

Fig. 14. Discernisporites sullivanii sp. nov., holotype, Ma6B 3641094.

Fig. 15. Discernisporites sullivanii sp. nov., Ma9A 1881028.

Fig. 16. Auroraspora solisorta Hoffmeister, Staplin \& Malloy, Ma9A 5131002.

Fig. 17. Densosporites spitsbergensis Playford, Ma6A 2301050. 

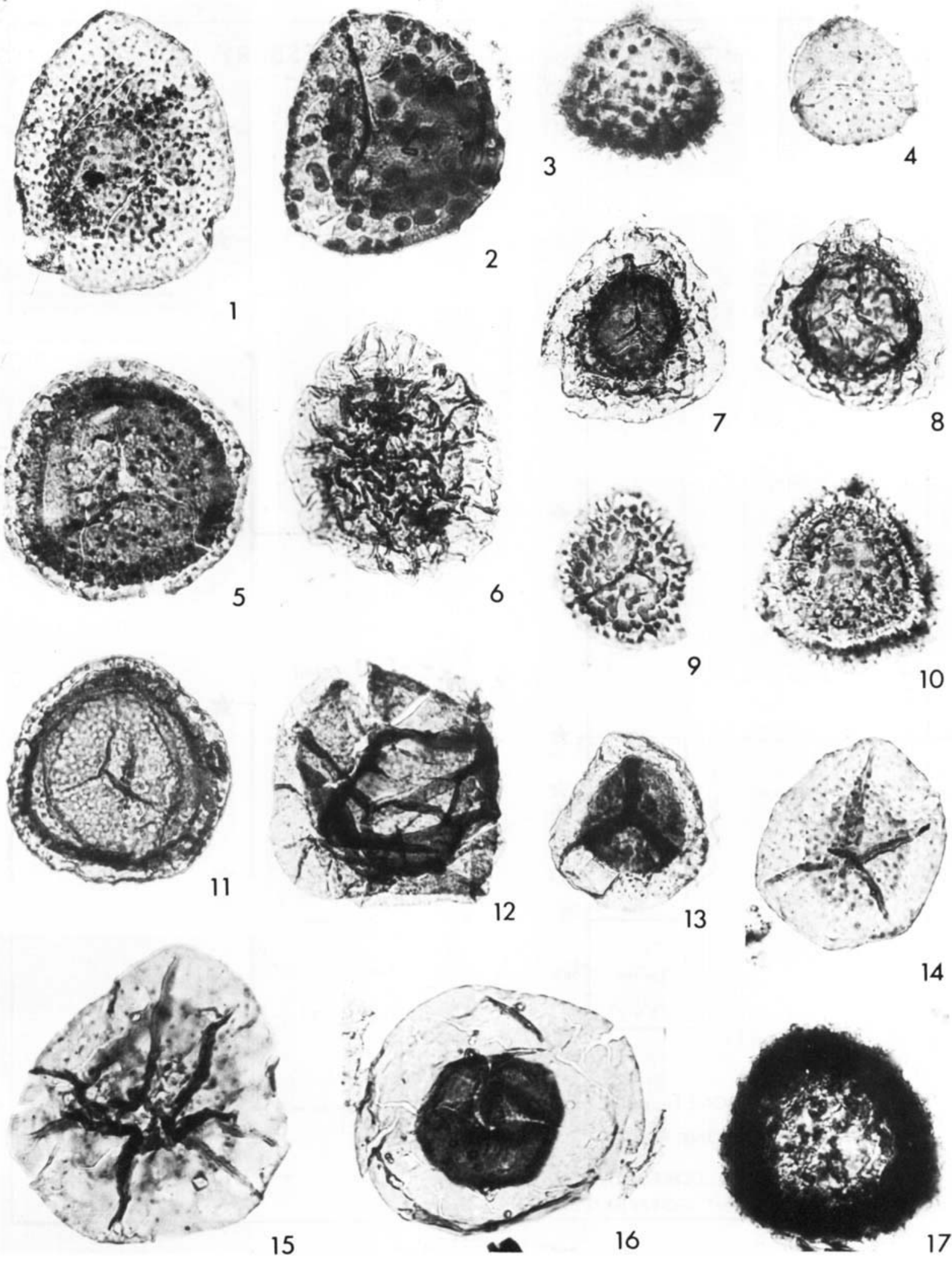

14

15

16

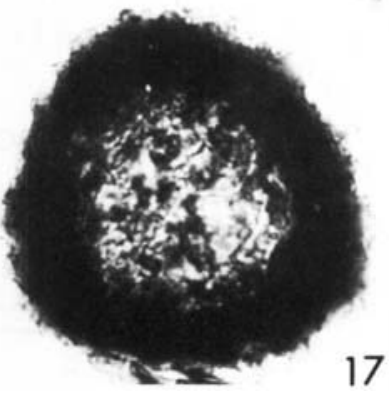




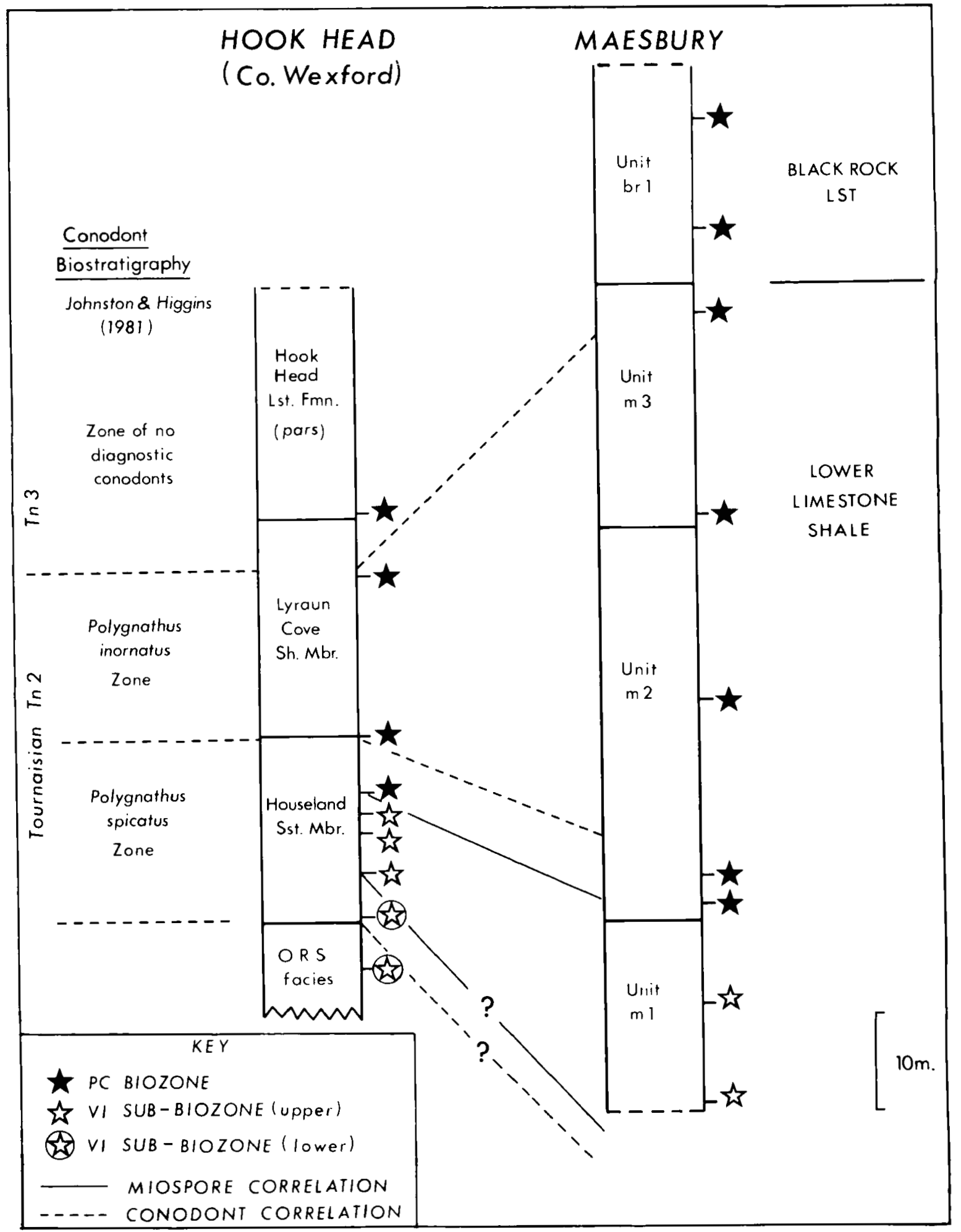

Fig. 4. Biostratigraphic correction of the Hook Head and Maesbury successions. 
assemblage from the Rhacophyton Bed is very limited in composition but appears to be representative of the lower part of the VI Sub-Biozone. The youngest assemblage type obtained from the middle and upper part of the Shirehampton Beds and the lower part of the Lower Limestone Shale (i.e. 0-27 m below the Bryozoa Bed and $2 \mathrm{~m}$ above the Bryozoa bed) is also assigned to the lower part of the VI Sub-Biozone. This assemblage is considered to be older than the VI Sub-Biozone assemblages recorded from Unit M1 at Maesbury.

\section{Forest of Dean}

Sullivan (1964) described miospores from two samples of the Lower Limestone Shale outcropping in the Wigpool Syncline in the Forest of Dean, Gloucestershire. Unfortunately, both samples were geographically isolated from one another and their position in the local stratigraphy is rather uncertain. Sullivan believed both samples occurred close to Unit 4 of Sibley \& Reynolds (1937) which is at a level slightly below the Bryozoa Bed. The microflora recorded by Sullivan contained the following group of species: Verrucosisporites nitidus (Naumova) Playford (as V. grumosus), Spelaeotriletes balteatus (Playford) Higgs, Lophozonotriletes tuberosus Sullivan, Raistrickia corynoges Sullivan (as Raistrickia sp. A), possibly Kraeuselisporites hibernicus Higgs (as Velosporites sp.) together with Baculatisporites fusticulus Sullivan and Umbonatisporites distinctus Clayton (pers. comm. Sullivan in Neves et al., 1972, p. 350). This assemblage is assigned to the upper VI Sub-Biozone and is closely comparable in composition with those obtained from Unit M1 at Maesbury. Stratigraphically this may indicate a position above, rather than below, the Bryozoa Bed, for the Forest of Dean samples.

\section{Hook Head}

The palynology of the 'Old Red Sandstone' and overlying marine sediments of Hook Head County Wexford, S.E. Ireland has been described by Dolby $(1970)$ and Higgs (1975). Miospore assemblages from the Porters Gate Formation compare closely with those from the Lower Limestone Shale at Maesbury.

The Upper VI Sub-Biozone assemblages from Unit M1 at Maesbury are similar in composition to that described by Higgs from sample 6 in the lower part of the Houseland Sandstone Member, as both contain Spelaeotriletes balteatus and Umbonatisporites distinctus. The PC Biozone assemblage from immediately above Unit M2 at Maesbury (sample Ma5) correlates well with the lowest PC Biozone assemblage recorded by Higgs at Hook Head (sample 7). Both assemblages contain the zonal species Spelaeotriletes pretiosus together with several of the new taxa described by Higgs e.g. Raistrickia condylosa, Kraeuselisporites mitratus, K. hibernicus, and Murospora dubitata.

\section{ACKNOWLEDGEMENTS}

The authors wish to thank Prof. L. R. Moore, Dr. E. Spinner and Dr. B. Higgs for assistance in the collection of samples and in the measurement of the section. Thanks are also due to Dr. S.C. Matthews and Dr. G.D. Sevastopulo for helpful discussion. One of the authors (K. H.) would like to thank Dr. C. Williams, Director of the Geological Survey of Ireland for permission to publish. 


\section{REFERENCES}

Bassett, M. G. \& Jenkins, T. B. H. 1977. Tournaisian conodont and spore data from the uppermost Shrinkle Sandstones of Pembrokeshire, South Wales. Geol. and Palaeontol., 11, 121-134.

Butler, M. 1973. Lower Carboniferous conodont faunas from the eastern Mendips, England. Palaeontology, London, 16, 447-517.

Clayton, G., Colthurst, J. R. J., Higgs, K., Jones, G. L. L. \& Keegan, J. B. 1977. Tournaisian miospores and conodonts from County Kilkenny. Geol. Surv. Ireland Bull., 2, 99-106.

Clayton, G. \& Higgs, K. 1979. The Tournaisian marine transgression in Ireland. J. Earth Sci. R. Soc. Dubl., 2, 1-10.

Clayton, G., Higgs, K., Keegan, J.B. \& Sevastopulo, G. D. 1978. Correlation of the palynological zonation of the Dinantian of the British Isles. Palinologia, 1, 137-147.

Clayton, G., Johnston, I. S., Sevastopulo, G. D. \& Smith, D. G. 1980. Micropalaeontology of a Courceyan (Carboniferous) borehole section from Ballyvergin, County Clare, Ireland. J. Earth Sci. R. Dubl. Soc., 3, 81-100.

Clayton, G. \& Sevastopulo, G. D. 1980. Discussion on the recognition and division of the Tournaisian Series in Britain. J. geol. Soc. London, 138, 104-105.

Dolby, G. 1970. Spore assemblages from the DevonianCarboniferous transition measures of south-west Britain and southern Eire. In Congrés Colloques Univ. Liège, 55, 267-274.

Dolby, G. \& Neves, R. 1970. Palynological evidence concerning the Devonian-Carboniferous boundary in the Mendips, England. Compte Rendu 6 me Congr. Avanc. Stratigr. Geol. Carbonif. (Sheffield 1967), 2, 631-646.

Gayer, R. A., Allen, K. C., Bassett, M. G. \& Edwards, D. 1973 The structure of the Taff Gorge area, Glamorgan and the stratigraphy of the Old Red Sandstone - Carboniferous Limestone transition. Geol. J., 8, 345-374.

George, T. N., Johnson, G. A. L., Mitchell, M., Prentice, J. E. Ramsbottom, W. H. C., Sevastopulo, G. D. \& Wilson, R. B. 1976. A correlation of Dinantian rocks of the British Isles. Geol. Soc. Lond. Spec. Rep., 7, 1-87.

Green, G. W. \& Welch, F. B. A. 1985. Geology of the country around Wells and Cheddar. Mem. Geol. Surv. G. B., 1-225.

Higgs, K. 1975. Upper Devonian and Lower Carboniferous miospore assemblages from Hook Head, County Wexford, Ireland. Micropaleontology, New York, 21, 393-419.

Johnston, I. S. \& Higgins, A. C. 1981 . Conodont faunas from the Lower Carboniferous rocks at Hook Head, County Wexford. J. Earth Sci. R. Dubl. Soc., 4, 83-96.

Keegan, J. B. \& Penney, S. R. 1978. Lower Carboniferous miospore assemblages from the Portlaw area, County Wexford, Ireland. Pollen et Spores, 20, 569-581.
Naumova, S. N. 1953. Spore-pollen complexes of the Upper Devonian of the Russian Platform and their stratigraphical significance. Trudy Inst. geol. Nauk Mosk, 143, 1-204.

Neves, R. 1958. Upper Carboniferous plant spore assemblages from the Gastrioceras subcrenatum horizon, North Staffordshire Geol. Mag., London, 95, 1-19.

Neves, R., Gueinn, K.J., Clayton, G., Ioannides, N.S. \& Neville, R.S.W. 1972. A scheme of miospore zones for the British Dinantian. Compte Rendu 7 me Congr. Avanc. Stratigr. Geol. Carbonif. (Krefeld, 1971), 1, 347-353.

Neves, R., Gueinn, K. J., Clayton, G., Ioannides, N. S., Neville, R. S. W. \& Kruszewska, K. 1973. Palynological correlations within the Lower Carboniferous of Scotland and Northern England. Trans. Roy. Soc. Edinb., 69, 23-70.

Owens, B. 1971. Miospores from the Middle and early Upper Devonian rocks of the Western Queen Elizabeth Islands, Arctic Archipelago. Geol Surv. Pap. Can., 70-38, 1-157.

Playford, G. 1971. Lower Carboniferous spores from the Bonaparte Gulf Basin, Western Australia and Northern Territory. Bull. Bur. Miner. Resour. Geol. Geophys. Aust., 115, 1-105.

Ramsbottom, W.H.C. \& Mitchell, M. 1980. The recognition and division of the Tournaisian Series in Britain. J. geol. Soc. London, 137, 61-63.

Sabry, H. \& Neves, R. 1971. Palynological evidence concerning the unconformable Carboniferous basal measures in the Sanquhar Coalfield, Dumfrieshire, Scotland. Compte Rendu 6 me Congr. Avanc. Stratigr. Geol. Carbonif. (Sheffield 1967), 4, 1441-1458.

Sibly, T.F. \& Reynolds, S. H. 1937. The Carboniferous Limestone of the Mitcheldean area, Gloucestershire. J. geol. Soc. London, 93, 23-51.

Sleeman, A. G., Johnston, I. S., Naylor, D. \& Sevastopulo, G. D. 1974. The stratigraphy of the Carboniferous rocks of Hook Head, County Wexford, Ireland. Proc. R. Ir. Acad., 74B, 227-243.

Sullivan, H.J. 1964. Miospores from the Lower Limestone Shales (Tournaisian) of the Forest of Dean, Gloucestershire. Compte Rendu 5 me Congr. Avanc. Stratigr. Geol. Carbonif. (Paris 1963), 3, 1249-1259.

Sullivan, H.J. 1968. A Tournaisian spore flora from the Cementstone Group of Ayrshire Scotland. Palaeontology, London, 11, 116-131.

Turnau, E. 1978. Spore zonation of uppermost Devonian and Lower Carboniferous deposits of Western Pomerania (N. Poland). Meded. Rijks Geol. Dienst., 30, 1-35. 